\title{
超高周波焰型放電の化學的研究 '(第二報)
}

(昭和十七年九月喓三日受嫆)

$$
\text { 水島三一郎㷊野米三水島容二郎 }
$$

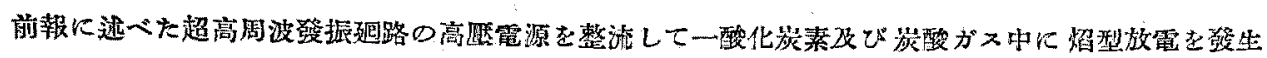

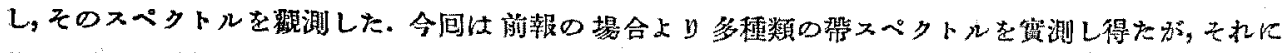

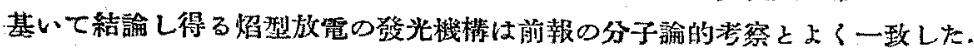

\section{緒言}

湔報》に於ては波長 $7 \mathrm{~m}$ の超高周波を用ひて一酸化炭素及び炭酸ガス中に焰型放電を發生せしd た結果に就て述べ，且そのスペクトルを筧測する事によつて放電の發光機構に對する 分子論的考察定

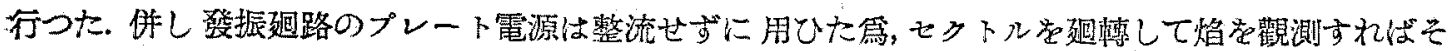
れが常に點隇してるるのが見られた。郎ち前報の研究は貫驗的には簡單であるが理論的に江種ふの要 素の入り込んだ複雜なものかも知れないのだある。方れ故本報に於ては整流された電源定用ひて超高 、周波を發生し，一酸化炭素及び炭酸ガス中に於ける焰型放電の觀测を繰返して前報の結論の再檢討㽓 行ふ專としたのである。

\section{實 驗 裝 置}

日本電氣株式會社製の水銀整流管 Q.C. $716 \mathrm{C} 2$ 個, $10 \mathrm{H}$ の塞流輪線, $12 \mu \mathrm{F}$ の蓄電器学用ひて全

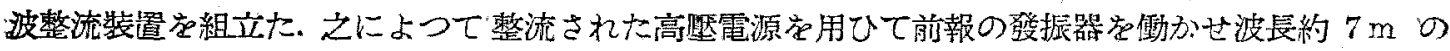
超高周波を發生した、同調迥路其他の裝置は前報のものと全く同梯であろ。

\section{實 驗 結 果}

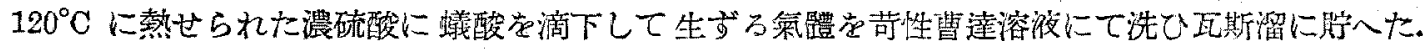
之学 Hempel の裝置によつて分析したこころ次の如き結果觉得た。

$\begin{array}{lr}\mathrm{CO} & 94.0 \% \\ \mathrm{~N}_{2} & 4.5 \% \\ \mathrm{O}_{2} & 1.5 \%\end{array}$

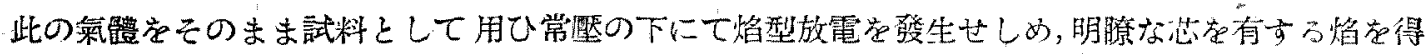
オ. そのスヘクトルを理研製 $\mathrm{E}_{2}$ 型分光器にて觀湘したところ，次の如き結果が得られた.23

a) 電 極 部

CO-Ångstrom 帶, CO-第3 正帶, CO-第 4 正帶,

$\mathrm{C}_{2}-\mathrm{Swan}$ 帶

$\mathrm{CN}$-赤带, $\mathrm{CN}$-紫帶,

$\mathrm{N}_{2}$-第 2 .正帶, $\mathrm{N}_{2}^{+}$帶, NO- $\gamma$ 帶

OH带

銅 (電嫩) の原子線

1）水島，䔉野，平林，柿原：本誌，63(1942)，31.

2) T壾のスペクトル以外に未知の带，或は他のもの上重 って检出の不能のるのが存した. 
b) 焰部

$\mathrm{C}_{2}-\mathrm{Swan}$ 帶,

$\mathrm{CN}$-赤帶, $\mathrm{CN}$-紫帶,

$\mathrm{OH}$ 帶

連緬スペクトル，

銅 (電極) の原于線

以上は通常の條件で發生す万安定な焰に就ての惯驗結果であろが，時として之と甚だ外觀の異る焰

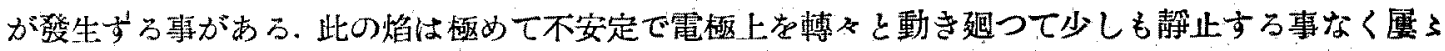

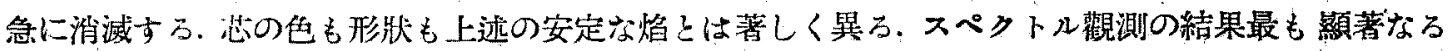
相違は此の不安定なる焻に於ては $\mathrm{OH}$ 帶が消失し， $\mathrm{C}_{2}$-Swan 帶が前より强く現れる事である.

台氣體の堅力を低下すれば常㻺では電極部のみに現れて乃た CO-Ångstrom 帶, CO-第 3 正帶等が 次第に焰部に摭つて來る事は前報の場合と同樣である。

次に大理石に監酸を注いで得られろ炭酸ガスを重曹䭂和溶滩及び硫酸銅濃溶液で洗ひ 監化カルシ

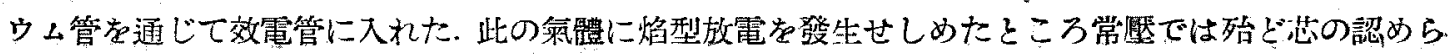
れない烚が、生じた. 觀測された主なスぺクトルは次の如くである。

a) 霾 椒 部

CO-Angstrom 帶, $\mathrm{CO}^{-}$第 3 正帶, CO-第 4 正帶,

$\mathrm{N}_{2}$-第2 正帶, $\mathrm{N}_{2}+$ 帶,

$\mathrm{OH}$ 帶,

連續スペクトル，

銅 (電極) の原子線

b) 熖部

$\mathrm{OH}$ 帶

連續スペクトル

銅 (電極)の原子線

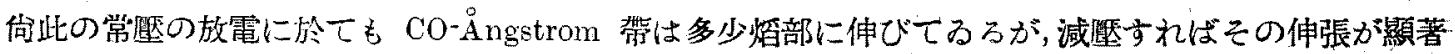
となる事は前報の場合と全く同樣である。

$\mathrm{C}_{2}-\mathrm{Swan}$ 帶が一酸化炭絜の場合にのみ現れ，咴酸ガスの場合には觀測されないと云ふ事實は放電の

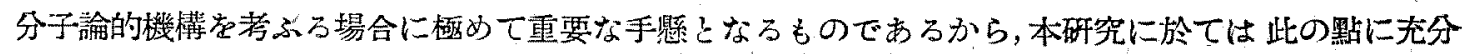

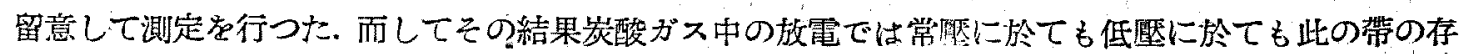
在しない事は確實となつた. 倘此の事苗と關聯して放電に件ふ炭素の遊離の問題が重要である. 而し

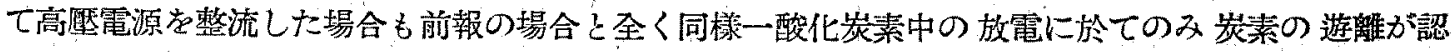
められ、炭酸ガスの場合にはこれが全く認められなかつた。

本研究に於ては前報の場合に比し，より多くの帶スペクトルが觀湘されたが，その結果は前報に述 ベたものと本質的に異るところはない.それ故前報で結論した放電の發光機構は正當であうた事が了 解される.即ち一酸化炭素の場合には電子衝突により

$$
\mathrm{CO} \rightarrow \mathrm{CO}^{*}
$$

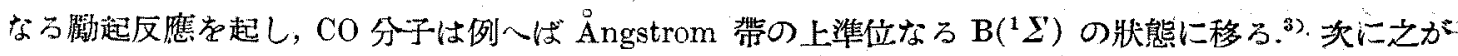
基底狀態にある $\mathrm{CO}$ 分子七衝突して

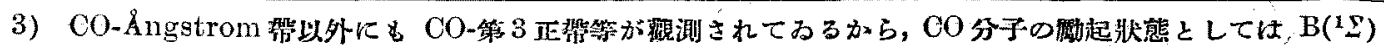

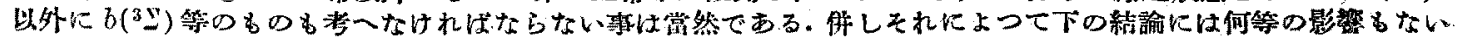
利は明かである。 


$$
\mathrm{CO}^{*}+\mathrm{CO} \rightarrow \mathrm{C}_{2}+\mathrm{O}_{2}
$$

なろ反應を起し，生成された $\mathrm{C}_{2}$ 分子によつて Swan 帶が生ずる. 叉炭酸がスの場合には電子衝突に よつて

となり,更に此の $\mathrm{CO}_{2}$ の蹷起分子が解離して

$$
\mathrm{CO}_{2} \rightarrow \mathrm{CO}_{2}^{*}
$$

$$
\mathrm{CO}_{2}^{*} \rightarrow \mathrm{CO}^{*}+\mathrm{O}
$$

となる.之によつて CO-Ångstrom 带; CO-第 3 正帶等の發生が說明されるが,連續スペクトルは

$$
\mathrm{CO}+\mathrm{O} \rightarrow \mathrm{CO}_{2}
$$

なっ再結合に起因方ものである.

之以外の分子機構も種々考へられるが，それ等は何れもェネルギー關係に於て不當である事は前報 に詳述した如くである。

一酸化炭素のとき $\mathrm{C}_{2}$-Swan 帶が觀測され炭酸ガスのときそれが觀測されない理由は次のェネル ギー關係によるものであつた。

$$
\begin{array}{r}
2 \mathrm{CO}=\mathrm{C}_{2}+\mathrm{O}_{2}-9.6 \text { e.v. } \\
\mathrm{CO}+\mathrm{CO}_{2}=\mathrm{C}_{2}+\mathrm{O}_{2}+\mathrm{O}\left({ }^{3} \mathrm{P}\right)-15.1 \text { e.v. }
\end{array}
$$

師ち $\mathrm{B}\left({ }^{1} \Sigma\right)$ 或は $b\left({ }^{3} \Sigma\right)$ の狀態にある $\mathrm{CO}^{*}$ 分子の過剩×ネルギーはそれぞれ 10.7 e.v. 或は 10.3 e.v. であろから (6) 式の反應は起し得ても (7) 式の反應は起し得ない. 郎ち $\mathrm{C}_{2}$ 分子の生成は一酸化炭素

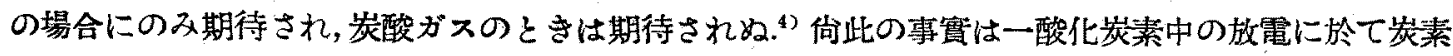
粉末の遊離を見, 炭酸ガスの場合はそれが見られなかつたと云ふ上記の結果ともよく一致する.

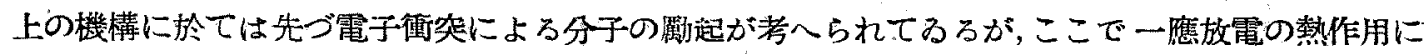
基く反應も檢討して置く必要がある. 此の目的の爲に我ぬは炭酸ガス中の煰型放電で發生した COẢngstrom 帶 $(0,1)$ の趈轉線の强度の 測定を行つた. 用ひた分光器は我ネの製作したもので高さ $10 \mathrm{~cm} の 60^{\circ}$ プリズム 1 個, $30^{\circ}$ プリズム 2 個, 徑 $12 \mathrm{~cm}$ 焦點距離 $150 \mathrm{~cm}$ の色消レンズ 1 個を Littrow 型に配置したものである. 又撮影されたスペクトルのフォトメーター曲線は理研製 B 型裝置 によつて求めた. 今呬轉線に於ける强度分布が Boltzmann 分布に從ふものとしてQ 枝の强度最大 の線の量子數上り電極附近の温度を決定すれば，塺力其他の條件によつて異るが，1000 $1500^{\circ}$ の 程度であ. 然るにかから溫度に於ける

$$
2 \mathrm{CO}_{2} \rightleftarrows 2 \mathrm{CO}+\mathrm{O}_{2}
$$

の平衡の解離度は $10^{-7} \sim 10^{-4}$ の程度に過ぎないから， $\mathrm{CO}_{2}$ より $\mathrm{CO}$ の生咸を全部熱反應として険明 する事は困難である. 特に Ångstrom 帶の黙力の變化による舉動を說明する事は出來ない.それ故我 そは分子の野起が主々して電子衝突に基くものと考へたのである。

以上迅へた如く高壓電源を整流した事によつて 放電の 分光學的及び化學的現象は本筫的に變化し なかつたのである.ただ熖が安定する事によつて前報の場合より多くの帶スペクトルを容易に觀测し 得たに過ぎない，前報に於ても亦本報に於ても我ふは未だ電氣的條件を完全に一定に保つてるるわけ ではないのである. 從つて既述の如く一酸化炭素の場合には芯のある熖が發生し, 炭酸がスの場合に

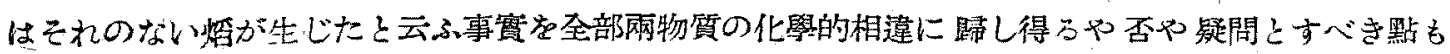
ある.併し從來我々が行つた數多の湘定の結果から考へて一酸化炭素及び炭酸ガス中に於ける焰型放 電の弡光の化學的機栫はその本筋に於て決定を見たものと考へて差支へないであらう.

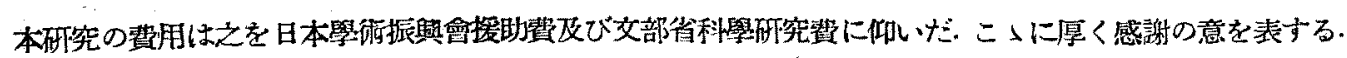

(東京偪學大學理學部化學教室)

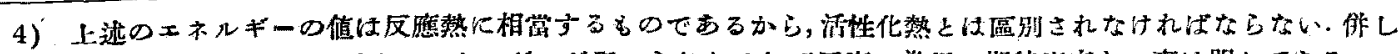

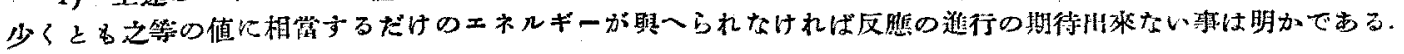

